\title{
Effect of stocking density and food ration on growth and survival of veliger and pediveliger larvae of the taquilla clam Mulinia edulis reared in the laboratory
}

Efecto de la densidad de cultivo y la ración de alimento en el crecimiento y supervivencia de larvas velígeras y pedivelígeras de la almeja taquilla Mulinia edulis cultivadas en el laboratorio

\section{Doris Oliva ${ }^{1,2}$, Alejandro Abarca ${ }^{2,3}$, Rodrigo Gutiérrez ${ }^{2}$, Lucía Herrera ${ }^{2}$, Ángela Celis ${ }^{2}$ and L. René Durán ${ }^{2}$}

'Instituto de Biología, Facultad de Ciencias, Universidad de Valparaíso, Gran Bretaña \#1111, Playa Ancha, Valparaíso, Chile. doris.oliva@uv.cl

${ }^{2}$ Centro de Investigación y Gestión de los Recursos Naturales (CIGREN), Universidad de Valparaíso, Gran Bretaña \#1111, Playa Ancha, Valparaíso, Chile

${ }^{3}$ Programa de Magister en Acuicultura, Facultad de Ciencias del Mar, Universidad Católica del Norte, Larrondo 1281, Coquimbo, Chile

Resumen.- Para evaluar el efecto de la densidad sobre el crecimiento y la sobrevivencia se cultivaron larvas velígeras de

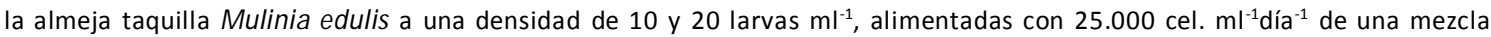
de Isochrysis aff. galbana (T-ISO) y Nannochloropsis oculata en recipientes de $5 \mathrm{~L}$. Para medir el efecto de la ración de alimento se utilizaron 25.000 y $50.000 \mathrm{cel}$. $\mathrm{ml}^{-1} \mathrm{dia}^{-1}$. Al final del experimento de densidad se encontraron diferencias en la supervivencia, pero no en el crecimiento. Las raciones de alimento experimentales no mostraron diferencias, ni en el crecimiento ni en la supervivencia larval. Para establecer el efecto de la densidad en el asentamiento, se cultivaron larvas pedivelígeras a densidades de 5, 10, 20 y 40 larvas $\mathrm{cm}^{-2}$, en un sistema down-welling. Para determinar la ración adecuada se usaron $25.000,50.000$ y 100.000 cel. $\mathrm{ml}^{-1} \mathrm{dí}^{-1}$ de T-ISO y un cuarto tratamiento con aumento progresivo del

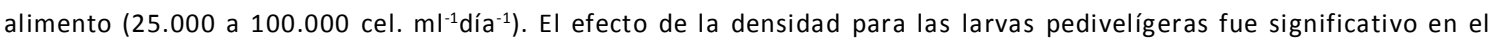
crecimiento y en la supervivencia. Las densidades más bajas presentaron mayores tamaños y supervivencia y las postlarvas alimentadas con una ración de $100.000 \mathrm{cel}$. $\mathrm{ml}^{-1} \mathrm{dí}^{-1}$ alcanzaron la mayor longitud valvar $(1728 \pm 293 \mu \mathrm{m})$. La mayor sobrevivencia (65\%) se obtuvo con la ración ascendente a la edad de 50 días desde larva D. Para mejorar la producción masiva de semillas, se recomienda utilizar una densidad inicial de 10 larvas $\mathrm{ml}^{-1}$ y una concentración de microalgas de 25.000 cel. $\mathrm{ml}^{-1} \mathrm{dí}^{-1}$. Para los cultivos postlarvales se recomienda una densidad de cultivo entre 5 y 10 larvas pedivelígeras $\mathrm{cm}^{-2}$ y una ración ascendente de alimento.

Palabras clave: Cultivo de almejas, larva D, postlarvas, Chile

Abstract.- In order to evaluate the effect of stocking density on growth and survival, veliger larvae of Mulinia edulis were reared at densities of 10 and 20 larvae $\mathrm{ml}^{-1}$ fed with a mix of 25,000 cells $\mathrm{ml}^{-1} \mathrm{day}^{-1}$ of Isochrysis aff. galbana (T-ISO) and Nannochloropsis oculata in $5 \mathrm{~L}$ buckets. In ration experiments, larvae were fed with of 25,000 and 50,000 cells $\mathrm{ml}^{-1}$ day $^{-1}$. By the end of the stocking experiment, significant differences were found in survival but not in larval growth rate. The ration experiment showed no differences in the growth nor in the survival of the larvae. To establish the effect of stocking density on settlement of pediveliger larvae, these were reared in a down-welling system at densities of 5, 10, 20 and 40 larvae $\mathrm{cm}^{-2}$. To determine an adequate food ration during settlement, pediveliger larvae were provided with $25,000,50,000$ and 100,000

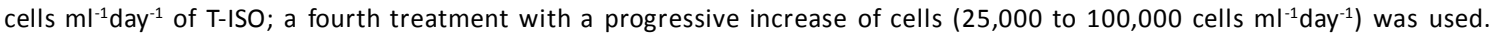

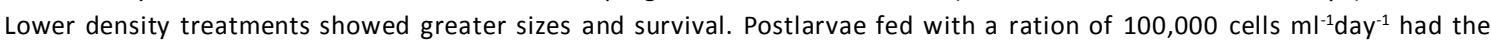
greatest valve length $(1728 \pm 293 \mu \mathrm{m})$. The progressive treatment had the best survival $(65 \%)$ at age 50 days from $D$ larvae. To improve the productivity of larval culture for a massive seed production an initial stocking density of 10 larvae $\mathrm{ml}^{-1}$ and a microalgae ration of 25,000 cells $\mathrm{ml}^{-1} \mathrm{day}^{-1}$ were recomended. For settlement stage we recommend a stocking density between 5 to 10 pediveliger $\mathrm{cm}^{-2}$ and the increasing food ration.

Key words: Clam aquaculture, D larvae, postlarvae, Chile 


\section{INTRODUCTION}

Native clam culture is emerging as an alternative to traditional fishery. Among Chilean clams, the taquilla clam Mulinia edulis (King \& Broderip, 1832) is a very apt species for artificial reproduction management for culturing, because of the presence of sexually mature specimens throughout the whole year (Oliva et al. 2005, Stotz et al. 2008, Jaramillo et al. 2008). Then, the presence of sexually mature specimens in most months of the year expedites the procurement of competent gametes for larval cultures. The estimated size at first sexual maturity is 31.9 $\mathrm{mm}$ and the mean fecundity is $8.35 \times 10^{6}$ oocytes per female (Oliva et al. 2005).

Also, this species is suitable to culturing because of their endurance to handling during the different rearing stages (Abarca et al. 2012, Oliva et al. 2013) and is highly marketable at about $30 \mathrm{~mm}$ as a 'baby' clam, although minimum harvest size regulations $(5.5 \mathrm{~cm})$ preclude this. Studies conducted by Stotz et al. (2008) in the Bay of Coquimbo demonstrated that only a small percentage of clam population exceeds the regulation size. In this way, aquaculture of small clams, has a great commercial potential.

Larval stocking density and feeding are relevant parameters for bivalve larval culture. It has been demonstrated that these parameters are closely related to growth and survivorship, as in the case of clams Mercenaria mercenaria (Loosanoff \& Davis 1963, Castagna \& Kraeuter 1981, Riisgard 1988), Paphia malabarica (Gireesh \& Gopinathan 2008) and Spisula solidissima (Goldberg 1989). Food rations used for larval culture can exceed 50,000 cells ml ${ }^{-1}$ day $^{-1}$ (Hurley et al. 1997, O’Beirn et al. 1997). However, although high food concentrations can increase growth rates, they may also elevate mortality rates, which are explained by decreases in filtering rates and metabolism associated with high concentrations of microalgae (Sprung 1984, Gallager 1988, Doroudi et al. 1999). It is also important to note that the supply of microalgae represents a critical point for hatcheries or seeding centres, accounting for up to $30 \%$ of the seed production cost (Coutteau \& Sorgeloos 1992).

Larval culture stocking density is inversely proportional to growth; bivalve larvae cultures with more than 20 larvae $\mathrm{ml}^{-1}$ increase their mortality and decrease growth rate (Hurley \& Walker 1996). Helm \& Bourne (2004) suggested a stocking density between 15-20 larvae $\mathrm{ml}^{-1}$ for Tapes philippinarum larvae culture and indicated that lower densities improved growth and survival.
The success of bivalve mollusc cultures, including clams, depends on the availability of seeds (Manzi \& Castagna 1989). The most critical stage of the production of seeds is the settlement, between a pediveliger larvae that initiates metamorphosis and postmetamorphic growth, until postlarvae reach a size of $1 \mathrm{~mm}$ (Helm \& Bourne 2004). Larvae are highly sensitive to environmental factors, which can affect their growth and therefore their artificial culture stages (Liu et al. 2006). The effects of density on clam culture are well documented (Hadley \& Manzi 1984, Beal \& Kraus 2002, Royo et al. 2002, Helm \& Bourne 2004, Royo et al. 2005); however many of these studies were mainly focused on juveniles (valvar lengths from $3.9 \mathrm{~mm}$ to $10-15 \mathrm{~mm}$ ), with very little attention to the postlarval stage. Liu et al. (2006) tested several stocking densities $\left(5,10,20,40\right.$ and 60 larvae $\left.\mathrm{ml}^{-1}\right)$ for the clam Meretrix meretrix to study their effect on larval settling, shell size, time and survival showing an inverse relationship between rearing density and larvae final size. Oliva et al. (2013) determined the effect on stocking density and type of diet on the growth and survival of $M$. edulis postlarvae cultivated in sand at densities of 5,10 and 20 postlarvae $\mathrm{cm}^{-2}$. The survival was about $40 \%$ in the 5 and 10 postlarvae $\mathrm{cm}^{-2}$ density treatments, but the final length was significantly higher in the 5 postlarvae $\mathrm{cm}^{-2}$ treatment $(2760 \pm 293 \mu \mathrm{m})$. The diet which produced the greatest growth was I. galbana (clone T ISO).

If survivorship and growth are parameters that varies according to the stocking density and food ration levels in veliger and pediveliger larvae, then an appropriate level of these variables allow us to select the best condition for culturing. In this context, the present study aims to show some characteristics of broodstock, spawning and larval culture and to establish the effect, on an experimental scale, of different food rations and stocking densities on the growth and survival of $M$. edulis veliger larvae; and the effect of different stocking densities in a down-welling system and food rations on the growth and survival during pediveliger settlement until postlarvae $>3 \mathrm{~mm}$, thus contributing to the development of a technology that allows the culturing of $M$. edulis on a commercial scale.

\section{Materials AND METHODS}

\section{BRoOdSTOCK, SPAWNING AND LARVAL CULTURE}

Broodstock of $M$. edulis were extracted from a natural bank in the bay of Tongoy, Chile $\left(30^{\circ} 18^{\prime} \mathrm{S} ; 71^{\circ} 32^{\prime} \mathrm{W}\right)$. The 
specimens were carried in an isothermal box with cold packs to the Pesquera San José S.A. hatchery, located in the same bay. To facilitate the expulsion of sand the clams were kept in filtered water for about $3 \mathrm{~h}$. The broodstock were induced to release gametes through temperature changes (Vivanco et al. 2014). The oocytes were fertilized with a proportion of 10 spermatozoa per oocyte and incubated in a $200 \mathrm{~L}$ tank with a density $20 \mathrm{eggs} \mathrm{ml}^{-1}$ in 1 $\mu \mathrm{m}$ filtered and UV sterilized sea water. After $48 \mathrm{~h}$, veliger larvae (D larvae) were obtained and used in the following experiments (Oliva et al. 2005). The age of the larva was calculated starting from the D larvae stage. The veliger larval experiments were performed with the same larval batch. The pediveliger larvae belonged to different batches produced in the same season.

\section{VELIGER LARVAE EXPERIMENTS}

\section{EFFECT OF STOCKING DENSITY ON VELIGER CULTURE}

Cultures were established with initial larval densities of 10 (control) and 20 larvae $\mathrm{ml}^{-1}$, with 3 replicates per treatment. Larvae were kept in buckets with $5 \mathrm{~L}$ of ultraviolet-sterilized sea water filtered at $1 \mu \mathrm{m}$, at a temperature of $18 \pm 1^{\circ} \mathrm{C}$ for 14 days. Continuous aeration was given along with a diet of 20,000 cells $\mathrm{ml}^{-1}$ day $^{-1}$ of Isochrysis aff. galbana (T-ISO clone) and 5,000 cells ml ${ }^{-1}$ day $^{-1}$ of Nannochloropsis oculata. Water was changed every second day. In order to estimate survival the larvae were sieved and concentrated in a $1 \mathrm{~L}$ container, homogeneously suspended by gentle agitation and a 1 $\mathrm{ml}$ aliquot was taken from each replicate and poured into a Sedgwick-Rafter chamber for observation in a trinocular Nikon ${ }^{\circledR}$ Eclipse E-200 microscope. From each sample, 30 larvae were selected randomly to measure shell length.

\section{EFFECT OF FOOD RATION ON VELIGER CULTURES}

M. edulis larvae were reared for 14 days in $40 \mathrm{~L}$ containers with ultraviolet-sterilized sea water filtered at $1 \mu \mathrm{m}$, at a temperature of $18 \pm 1^{\circ} \mathrm{C}$; and fed with 25,000 cells $\mathrm{ml}^{-1}$ day $^{-1}$ (control) and 50,000 cells ml ${ }^{-1}$ day $^{-1}$ of a mix of T-Iso and $N$. oculata in a proportion of $4: 1$ once per day. The cultures, with 3 replicates, were established with an initial density of 10 larvae $\mathrm{ml}^{-1}$, with continuous aeration. Water was changed every other day, with counts, survival estimation and growth measurements as in the previous experiment.

\section{Pediveliger larval experiments}

\section{EFFECT OF STOCKING DENSITY ON PEDIVELIGER CULTURE}

This experiment was performed with pediveligers larvae of $245 \pm 10 \mu \mathrm{m}$ shell length, coming from a 14 day-old culture of larvae fed with a standard food ration of 25,000 cells $\mathrm{ml}^{-1}$ day $^{-1}$ at an initial stocking density of 10 larvae $\mathrm{ml}^{-1}$ and sea water at $18 \pm 1^{\circ} \mathrm{C}$. The densities tested were 5, 10 (control), 20 and 40 pediveliger larvae $\mathrm{cm}^{-2}$. Pediveliger larvae were cultured in a down-welling system consisting of a $254 \mathrm{~cm}^{2}$ sieve base (where larvae are settled) with a mesh of $177 \mu \mathrm{m}$ (USA Standard ASTM 80), placed in a tray at a temperature of $18 \pm 1^{\circ} \mathrm{C}$ with $25 \mathrm{~L}$ of seawater filtered at $1 \mu \mathrm{m}$ and sterilized with UV light. Water flows from the tray to the sieve by air thrust through a 20 $\mathrm{mm}$ PVC tube. Larvae were fed with a fixed ration of 25,000 cells $\mathrm{ml}^{-1}$ day $^{-1}$ once per day and the water was replaced every second day. The experiment was performed in triplicate; postlarvae were counted every sixth day for 30 days to establish their survival rates; 30 postlarvae were measured in each sample to analyse growth rates.

\section{EFFECT OF FOOD RATION ON PEDIVELIGER CULTURE}

Experiments to evaluate the effect of food ration were performed with 15 days old pediveliger larvae with an initial length of $290 \pm 10 \mu \mathrm{m}$. They were cultured in a static system in $1 \mathrm{~L}$ trays with a basal area of $160 \mathrm{~cm}^{2}$. Trays were provided with a $1 \mathrm{~cm}$ layer of fine sand sieved with a $300 \mu \mathrm{m}$ sieve and with microfiltered and UV-sterilized seawater at a temperature of $18 \pm 1^{\circ} \mathrm{C}$. The water was replaced every second day.

Each tray began with around 960 larvae, which were fed with rations of 25,000 (control), 50,000 or 100,000 cells $\mathrm{ml}^{-1}$ day $^{-1}$ of Isochrysis aff. galbana (clon T-ISO); a fourth trial began with 25,000 cells $\mathrm{ml}^{-1}$ day $^{-1}$ and was increased by 25,000 cells every 7 days up to 100,000 cells $\mathrm{ml}^{-1}$ day $^{-1}$ once per day. Each treatment was replicated four times; growth were recorded every 7 days and survival at the end of the experiment (at age 50 days from D larvae).

\section{Statistical analysis}

The Shapiro test was used to evaluate the normality of the growth data (shell lengths). The effect of stocking density and food rations on growth of larval cultures was analysed using the Kruskal-Wallis non-parametric test. The same test was used for the evaluation of stocking density on the growth of the postlarval cultures; while 
for a posteriori analyses the Mann-Whitney U test was used (Sokal \& Rohlf 2012). Survival data were arcsine transformed for further analysis. To evaluate the effect of food ration and stocking density on larval and postlarval survival, an ANOVA was used along with the $a$ posteriori Fisher test (Sokal \& Rohlf 2012). $P<0.05$ was used as a significance criterion for all tests.

\section{Results}

\section{BroODSTOCK, SPAWNING AND LARVAL CULTURE}

Mulinia edulis has separate sexes and no external sexual dimorphism. The female gonads have a dark purple colour, while male gonads have an orange-yellow colouring. The gametes, of whitish colour in males and red colour in females, are expelled to the environment.

The oocytes obtained after the induction of gamete expulsion are spherical and of red colour, with a mean diameter of $58 \pm 1.9 \mu \mathrm{m}$. The average fecundation rate was $74 \pm 10 \%$. After $48 \mathrm{~h}$ from fecundation, the resulting veliger larvae have a ' $D$ ' shape with a straight hinge, and measure an average of $93.7 \pm 5.4 \mu \mathrm{m}$. They present a ciliated structure, the velum, which allows the larvae to swim freely and catch food. Five days later the umbo of the larvae is conspicuous (Fig. 1).

After 3 to 5 days, the first umbonate larvae were found with a contractile organ covered with cilia, corresponding to the foot. This occurred at a mean shell length of 245 $\mu \mathrm{m}$. From 2 to 4 days later, the entire batch presented a foot (Fig. 1). The pediveliger swimming larva transforms

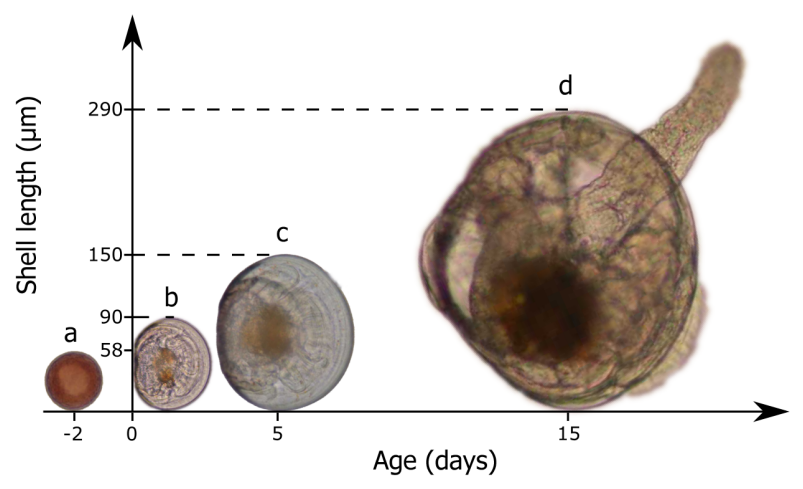

Figure 1. Larval development of the taquilla clam Mulinia edulis. (a) fecundated oocyte $(58 \mu \mathrm{m})$, (b) $48 \mathrm{~h}$ old veliger larvae (D larvae) $(94$ $\mu \mathrm{m})$, (c) 5 day old umbonated veliger $(150 \mu \mathrm{m})$, (d) 15 day old pediveliger $(290 \mu \mathrm{m})$ / Desarrollo larvario de la almeja taquilla Mulinia edulis. (a) ovocito fecundado $(58 \mu \mathrm{m})$, (b) larvas veliger de 48 $\mathrm{h}$ de edad (larvas D) $(94 \mu \mathrm{m})$, (c) larva velígera umbonada de 5 días de edad $(150 \mu \mathrm{m})$, (d) larva pedivelígera de 15 días de edad $(290 \mu \mathrm{m})$ into a benthic organism when it sheds its velum at age 22 days and $0.5 \mathrm{~mm}$ length. This clam pediveliger larva does not present an eyespot. The metamorphosed larva has all the morphological characteristics of an adult when 28 days old and hereinafter is called postlarvae.

\section{VELIGER LARVAE EXPERIMENTS}

\section{EFFECT OF STOCKING DENSITY IN VELIGER CULTURE}

After 14 days of culture (starting from D larvae) M. edulis larvae reached shell lengths of $223 \pm 22.9 \mu \mathrm{m}$ and $216 \pm$ $21.2 \mu \mathrm{m}$ in cultures with initial densities of 10 and 20 larvae $\mathrm{ml}^{-1}$, respectively. No significant length difference between densities was found throughout almost the entire experiment (Fig. 2A), with the exception of day 8. The larval daily growth rate during the culture period was 9.2 $\mu \mathrm{m}$ day $^{-1}$ for the lower density (10 larvae $\mathrm{ml}^{-1}$ ) cultures and $8.8 \mu \mathrm{m} \mathrm{day}^{-1}$ for cultures of 20 larvae $\mathrm{ml}^{-1}$.

Larval survival was significantly greater at 10 larvae $\mathrm{ml}^{-1}(43.9 \pm 4.4 \%)$ than at 20 larvae $\mathrm{ml}^{-1}(24.1 \pm 0.9 \%$ ) (Fig. $2 \mathrm{~B})$. At the end of the experiment both treatments had a similar larval density; 4.82 for the 10 larvae $\mathrm{ml}^{-1}$ treatment and 4.4 for 20 larvae $\mathrm{ml}^{-1}$.
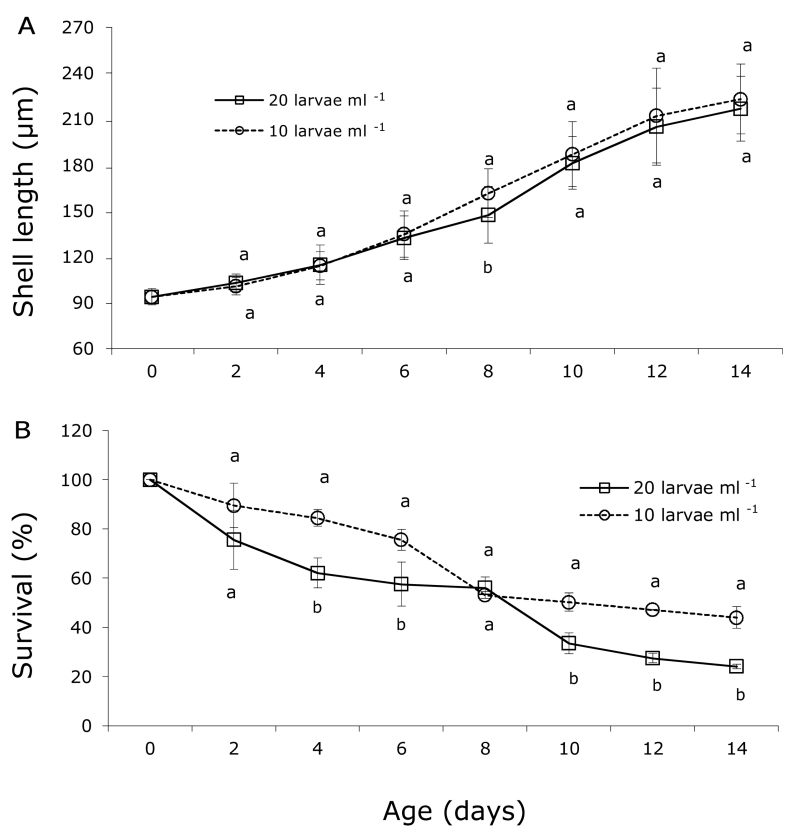

Figure 2. Growth (A) and survival (B) of Mulinia edulis larvae reared at two experimental densities: 10 and 20 larvae $\mathrm{ml}^{-1}$. Means with different letters are significantly different $(P<0.05) /$ Crecimiento (A) y supervivencia (B) de larvas de Mulinia edulis cultivadas en dos densidades experimentales: 10 y 20 larvas $\mathrm{ml}^{-1}$. Los promedios con letras diferentes son significativamente diferentes $(P<0,05)$ 


\section{EFFECT OF FOOD RATION ON VELIGER CULTURE}

Larvae fed with a daily ration of 25,000 cells $\mathrm{ml}^{-1}$ day $^{-1}$ reached a mean length of $225.9 \pm 23 \mathrm{~mm}$ by the $14^{\text {th }}$ day of culture, while those fed with 50,000 cells ml ${ }^{-1} \mathrm{day}^{-1}$ reached a length of $229 \pm 20 \mathrm{~mm}$ (Fig. 3A); the difference was not significant. Daily growth rate was 8.07 and $8.27 \mathrm{~mm} \mathrm{day}^{-1}$ for larvae fed with 25,000 and 50,000 cells ml $\mathrm{may}^{-1}$, respectively.

The survivorship was similar for both treatments; 34.4 $\pm 12 \%$ for cultures fed with 25,000 cells ml ${ }^{-1}$ day $^{-1}$ and 34.9 $\pm 7 \%$ for cultures fed with 50,000 cells $\mathrm{ml}^{-1}$ day $^{-1}$ (Fig. 3B).

\section{Pediveliger larvae experiments}

\section{EFFECT OF STOCKING DENSITY ON PEDIVELIGER CULTURE}

Around age 26 days the metamorphosis occurred, and from that until the end of the experiment, postlarval growth was significantly affected by density. The treatment with 5 pediveliger $\mathrm{cm}^{-2}$ presented the greatest shell lengths from age 26 days onwards throughout the entire study
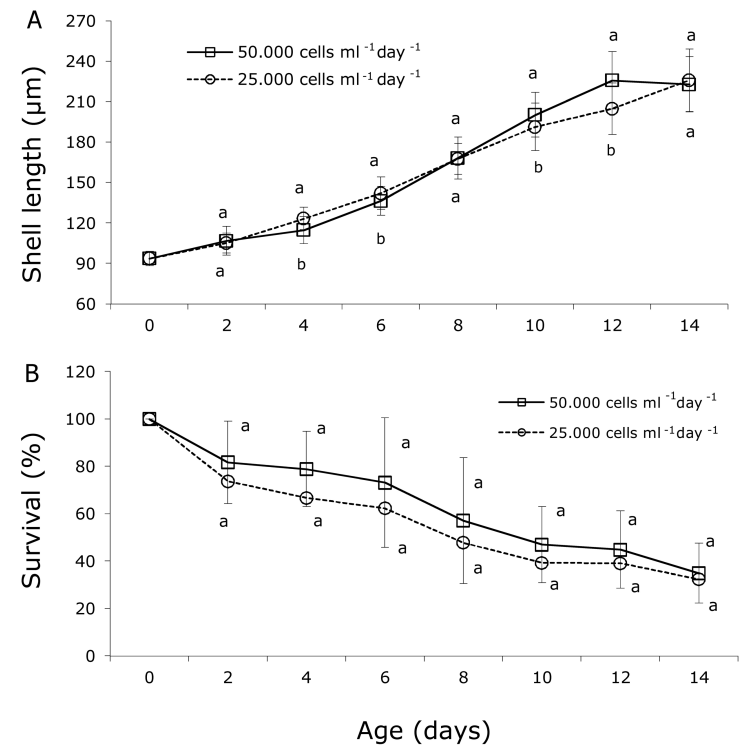

Figure 3. Growth (A) and survival (B) of Mulinia edulis larvae reared with two experimental food rations: 25,000 and $50,000{\text { cells } \mathrm{l}^{-1}}^{-1}$ day $^{-1}$ of microalgae per day. Means with different letters are significantly different $(P<0.05)$ / Crecimiento $(A)$ y supervivencia (B) de larvas de Mulinia edulis cultivadas con dos raciones de

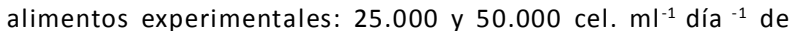
microalgas por día. Los promedios con letras diferentes son significativamente diferentes $(P<0,05)$ period $(2370 \pm 554 \mu \mathrm{m})$ and the mean daily growth rate was $71 \mu$ day $^{-1}$ (Fig. 4A). Postlarvae kept at an initial stocking density of 10 pediveliger $\mathrm{cm}^{-2}$ presented a greater growth $(1733 \pm 331 \mu \mathrm{m})$ than those kept at an initial density of $20(1309 \pm 276 \mu \mathrm{m})$ and $40(1260 \pm 276 \mu \mathrm{m})$ pediveliger $\mathrm{cm}^{-2}(P<0.05)$.

At age 20 days, survival fell sharply to $49.8 \pm 15 \%$ in the 40 pediveliger $\mathrm{cm}^{-2}$ treatment (Fig. 4B), which stood as the lowest of the treatments. Survival decreased to $80 \%$ in the other treatments, with no significant difference between them. There was no significant difference between treatments at age 26 and 32 days; however, survival was affected by density at age 38 and 44 days. The 40 pediveliger $\mathrm{cm}^{-2}$ treatment had the lowest survival; $32 \pm 7 \%$ at the end of the experiment. Survival in the 5 and 10 pediveliger $\mathrm{cm}^{-2}$ treatments presented no significant differences during the entire experiment, with percentages of $68 \pm 9 \%$ and $64 \pm 22 \%$, respectively at the end of the experiment. The 20 pediveliger $\mathrm{cm}^{-2}$ treatment was suspended at age 32 days, because the replicates were contaminated with protozoa.
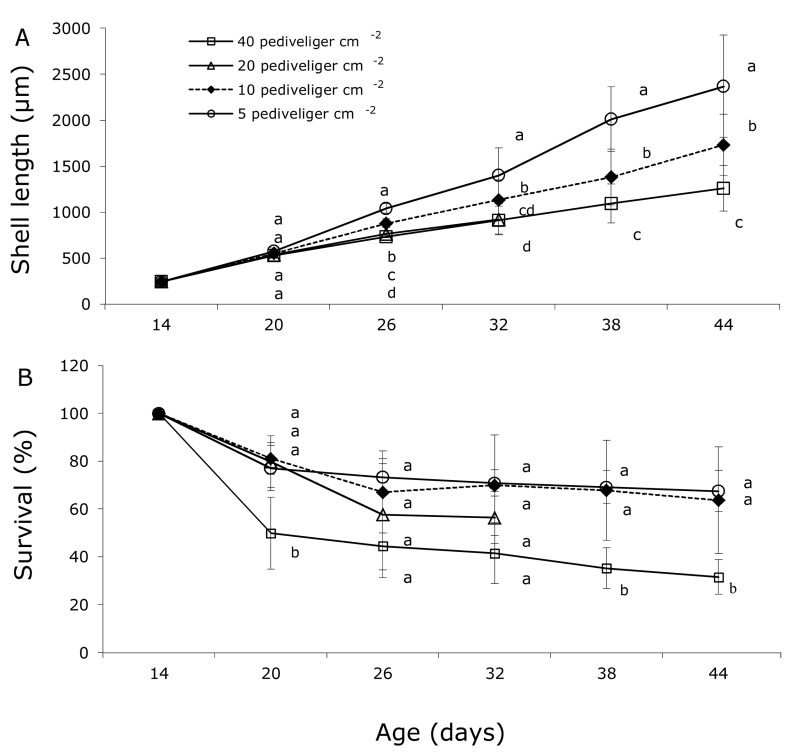

Figure 4. Growth (A) and survival (B) of Mulinia edulis postlarvae reared in a down-welling system with 4 densities $(5,10,20$ and 40 pediveliger $\mathrm{cm}^{-2}$ ). Means with different letters are significantly different $(\mathbf{P}<\mathbf{0 . 0 5})$ / Crecimiento $(A)$ y supervivencia $(B)$ de postlarvas de Mulinia edulis cultivadas en un sistema downwelling con 4 densidades $\left(5,10,20\right.$ y 40 pediveliger $\left.\mathrm{cm}^{-2}\right)$. Los promedios con letras diferentes son significativamente diferentes $(P<0,05)$ 


\section{EFFECT OF FOOD RATION ON PEDIVELIGER CULTURE}

The shell length of postlarvae was significantly affected by food concentration (Fig. 5). Those fed with 25,000 or 50,000 cells $\mathrm{ml}^{-1}$ day $^{-1}$ grew slower than those fed with 100,000 cells $\mathrm{ml}^{-1} \mathrm{day}^{-1}$, and the difference was already significant at day 14 . Those fed with the progressive increase of cells fell behind the 100,000 cell treatment in the first two weeks (when they received less food), and never quite caught up to the 100,000 cell treatment, although they maintained a similar growth rate once they received the maximum food. Interestingly, all treatments grew at about the same rate until age 22 days; the differences were established during the second week of the experiment. The overall daily growth rates of the postlarvae for the five weeks of the experiment were 25

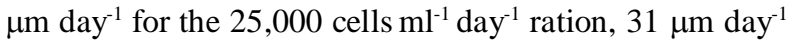
for the 50,000 cells ration, $41 \mu \mathrm{m} \mathrm{day}^{-1}$ for the 100,000 cells ration, and $38 \mu \mathrm{m} \mathrm{day}^{-1}$ for the progressive treatment. The maximum and minimum mean shell lengths at the end of the experiment were $1728 \pm 293$ and $1153 \pm 214 \mu \mathrm{m}$ for the 100,000 and 25,000 cells $\mathrm{ml}^{-1}$ day $^{-1}$ rations, respectively; all four treatment means were significantly different at the end of the experiment (Fig. 5).

Figure 6 shows the mean survival for the different food rations. The best survival $(65.5 \%)$ was in the progressive ration treatment, and the poorest was in the postlarvae fed with 25,000 cells ml ${ }^{-1}$ day $^{-1}(49.1 \%)$.

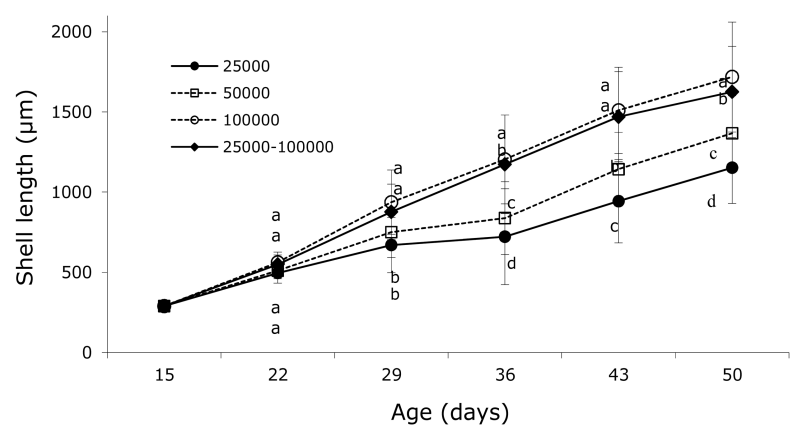

Figure 5. Growth of Mulinia edulis postlarvae reared in a closed system with sand with 4 different food rations $(25,000,50,000$, 100,000 cells ml$^{-1}$ day $^{-1}$ and $25,000-100,000$ cells ml $l^{-1}$ day $^{-1}$ ). Means with different letters were significantly different $(P<0.05) /$ Crecimiento de postlarvas de Mulinia edulis cultivadas en un sistema cerrado con arena y con 4 raciones de alimentos

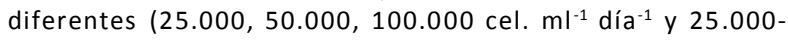
$\left.100.000 \mathrm{cel} \mathrm{ml}^{-1} \mathrm{dí}^{-1}\right)$. Promedios con letras diferentes son significativamente diferentes $(P<0,05)$

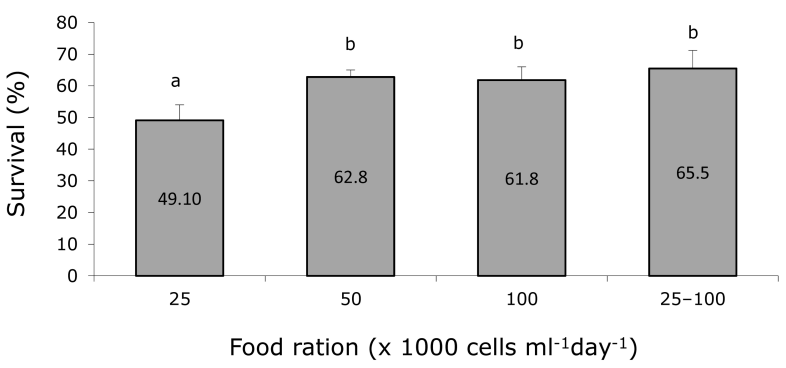

Figure 6. Survival of $\mathbf{5 0}$ days old Mulinia edulis postlarvae reared in a closed system with sand with 4 different food rations $(25,000$, $50,000,100,000$ cells $\mathrm{ml}^{-1}$ day $^{-1}$ and $25,000-100,000$ cells $\mathrm{ll}^{-1}$ day $\left.^{-1}\right)$. Means with different letters were significantly different $(P<0.05)$ / Supervivencia de postlarvas de Mulinia edulis de 50 días de edad, cultivadas en un sistema cerrado con arena y con 4 raciones de alimentos diferentes $\left(25.000,50.000,100.000\right.$ cel. ml $^{-1}$ día $^{-1} \mathrm{y}$ 25.000-100.000 cel. $\mathrm{ml}^{-1}$ día $\left.^{-1}\right)$. Promedios con letras diferentes son significativamente diferentes $(P<0,05)$

\section{Discussion}

The best results in terms of growth and survival in larval cultures for $M$. edulis were obtained with control density, 10 larvae $\mathrm{ml}^{-1}$. Although no significant difference was found between the growth of the 10 and 20 larvae $\mathrm{ml}^{-1}$ treatments, the culture that began with a density of 10 larvae $\mathrm{ml}^{-1}$ showed significantly greater survival. Hurley $\&$ Walker (1996) found no significant difference rearing cultures of Spisula solidissima similis at densities of 10 , 20, 30 and 50 larvae $\mathrm{ml}^{-1}$, but found a significant difference for growth, which was greater for larvae cultured at the lower density of 10 larvae $\mathrm{ml}^{-1}$. These authors proposed that the greater growth at 10 larvae $\mathrm{ml}^{-1}$ could be due to the fact that at this density larvae have a greater availability of food than larvae kept at greater densities. This may have been the case for M. edulis, since the food ration was four times smaller $\left(25,000\right.$ cells $\mathrm{ml}^{-1}$ day $\left.^{-1}\right)$ than that used by Hurley \& Walker (1996). On the other hand, Yan et al. (2006), working with the japanese clam Ruditapes philippinarum, found no difference in growth between densities of 10,15 and 20 larvae $\mathrm{ml}^{-1}$. Larval cultures of the clam Meretrix meretrix (Liu et al. 2006) at densities of 5, 10, 20, 40 and 60 larvae $\mathrm{ml}^{-1}$ presented the same tendency, showing no difference for densities of 10, 20 and 40 larvae $\mathrm{ml}^{-1}$, and a difference for 5 larvae $\mathrm{ml}^{-1}$, which presented a greater growth. Liu et al. (2006) recommend using moderate densities of 10 to 20 larvae $\mathrm{ml}^{-1}$ for massive hatchery production, because they allow rapid growth, short settling times and high survival rates. 
The decrease in survival of cultures with an initial density of 20 larvae $\mathrm{ml}^{-1}$ may be explained according to the proposition of Liu et al. (2006), which attributes high mortality in larviculture to poor water quality or diseases. As the stocking density increases, more metabolic waste matter is accumulated in the water, which produces a decrease in its quality and also if the ration is equal for different larval densities than the availability of food is inversely to the stocking density. Larvae of $M$. edulis showed no significant difference larval growth or survivorship between the daily rations of 25,000 and 50,000 cells $\mathrm{ml}^{-1}$ day $^{-1}$. This suggests that 25,000 cells mll ${ }^{-1}$ day $^{-1}$ may be sufficient for the larval culture stage and the daily growth rate obtained was similar to the growth reported by other authors who used greater rations such as Hurley \& Walker (1996), who fed Spisula. solidissima similis larvae with rations of 100,000 cells $\mathrm{ml}^{-1}$ day $^{-1}$; and O'Beirn et al. (1997), with rations of 50,000 and 75,000 cells $\mathrm{ml}^{-1}$ day $^{-1}$ for larvae of $S$. solidissima solidissima.

High microalgae rations affect the survivorship of cultures, because those cells that are not eaten by larvae suffer microbial decomposition processes, exposing cultures to noxious bacteria and fungi (Loosanoff \& Davis 1963, Helm \& Bourne 2004, Liu et al 2006). This was corroborated by Hurley et al. (1997), who concluded that rations greater than 200,000 cells $\mathrm{ml}^{-1}$ day ${ }^{-1}$ are excessive and are less productive, finding that the optimal for good growth and survival of $S$. solidissima similis larvae is a ration somewhere between 50,000 and 100,000 cells $\mathrm{ml}^{-1}$ day ${ }^{1}$.

The greater food availability for larvae fed with 50,000 cells $\mathrm{ml}^{-1}$ day $^{-1}$ showed no positive effect on the growth and/or survivorship of larvae of $M$. edulis, however, the effect of a better nutrition could express itself in the metamorphosis stage, either by increasing survivorship or by shortening the stage (Marshall et al 2010).

The veliger larvae were fed with a mixed diet of Isochrysis aff. galbana (T-ISO clone) and Nannochloropsis oculata. Vivanco et al. (2014) assessed the effect of nine different diets on growth and survival of $M$. edulis veliger larvae. The best results (shell length $=272 \mu \mathrm{m}$; growth rate $=9.2$ $\mu \mathrm{m}$ day $^{-1}$ ) were obtained with that a mixed diet including Isochrysis aff. galbana (T-ISO clone). Nevertheless, in postlarvae the suggested diet is a unialgal T-ISO clone diet (Oliva et al. 2013).

The settling stage, between the appearance of the foot and the loss of the velum, has no diagnostic character in M. edulis, like in other clam species. Tapes clams show no evidence of an eyespot (Jones et al. 1993), nor do Chilean clam larvae of Venus antiqua and Gari solida (Olavarría et al. 1996).
The size of postlarvae stocked at 5 pediveliger $\mathrm{cm}^{-2}$ was $28 \%$ greater than that of postlarvae stocked at 10 pediveliger $\mathrm{cm}^{-2}$. According to Liu et al. (2006), stocking density affects not only larval development rate, but also the size (shell length) that it reaches once the pelagic phase ends, as we found for M. edulis.

M. edulis begins the pediveliger stage with the appearance of the foot, at a medium shell length of $245 \mu \mathrm{m}$. This happens between days 14 and 16 at a temperature of $18^{\circ} \mathrm{C}$ (this study) and between days 18 and 20 at $15^{\circ} \mathrm{C}$ (Vivanco et al. 2014). For Venus antiqua and Gari solida, two other commercial chilean clams, the pediveliger size is $310 \mu \mathrm{m}$ and $279 \mu \mathrm{m}$ at 25 and 31 days of culture respectively (Olavarría et al. 1996) with temperatures between 16 and $18^{\circ} \mathrm{C}$ (Bustos \& Olavarría 2000). As mentioned previously, in the larval stage at higher densities in cultivation, metabolic waste matter could affect larval growth. The same effect may occur during postlarval growth. On the other hand, competition for space and food could explain the greater growth reached by postlarvae kept at lower densities (Yan et al. 2006).

Interspecies discrepancies make comparison between different clam species difficult. One example of such differences is the case of Cyclina sinensis (Liu et al. 2002), which has a much shorter larval time and smaller size at metamorphosis than $M$. edulis, which allows $C$. sinensis to endure higher stocking densities in the postlarval stage (723 postlarvae $\mathrm{cm}^{-2}$ ).

Survivorship was affected by density; the best results were obtained in postlarvae stocked at 5 and 10 pediveliger $\mathrm{cm}^{-2}$, with 68 and $64 \%$ survivorship, respectively. This survivorship is greater than that reported by Liu et al. 2002, which was $57.6 \%$, however, they ended with a density of 723 postlarvae $\mathrm{cm}^{-2}(259 \mu \mathrm{m})$ versus $M$. edulis, which ended with a density of 7 postlarvae $\mathrm{cm}^{-2}(2377 \mu \mathrm{m})$.

For M. edulis, the stocking density used during the postlarval stage is an important factor for growth and survivorship, unlike the larval stage. Therefore this species requires special conditions for each developmental stage to obtain greater culture efficiency. By comparing the pediveliger larvae stocking density experiments in a close system with sand (Oliva et al. 2013) with a down-welling system (at $18 \pm 1^{\circ} \mathrm{C}$ ), in both cases the best results were obtained in the 5 and 10 pediveliger $\mathrm{cm}^{-2}$ treatment. But the survival is much higher in the down-welling system in 5 and 10 pediveliger $\mathrm{cm}^{-2}$ treatment (68 and 64\%) than in the close system with sand (38 and 40\%).

Different food rations had a significant effect on the increase of valve length of postlarvae of $M$. edulis. In this stage of growth, a fixed ration of 100,000 cells $\mathrm{ml}^{-1}$ day $^{-1}$ and 
the increasing treatment were optimal for good growth in a closed culture system with a sandy bottom.

The optimization of food availability can maximize larval growth and minimize hatchery costs (Doroudi \& Southgate 2000). Knowing the optimum food concentration for postlarvae allows us to be efficient in hatchery culture costs, since an insufficient food concentration produces sub-optimal growth and overfeeding increases hatchery costs and may reduce the water quality, which may affect postlarval growth and survival. Excessive food concentrations may interfere with the food capture mechanisms of these bivalves; some of the filtered particles may be eliminated as pseudofeces, thus reducing the rate of ingestion (Albentosa et al. 1996). Also, the reduction in filtration rate due to high concentrations of microalgae was associated with the maximum retention time in the intestine, valve closing, reduction of metabolism and reduction in biosynthesis, and thus growth (Riisgard 1991).

Ingestion rate and absorption efficiency are physiological processes which affect the growth of seeds. In the case of the clam Ruditapes decussatus, the rate of ingestion increased with food concentration, but only up to a maximum of 100,000 cells $\mathrm{ml}^{-1} \mathrm{day}^{-1}$; a greater concentration produced a decrease in ingestion (Albentosa et al. 1996).

Food concentration had no effect on the survival of the postlarvae of $M$. edulis; except for the 25,000 cells $\mathrm{ml}^{-1}$ day $^{-1}$ treatment. There were no significant differences at any of the three higher concentrations used. We obtained a mean survival between 62 and $65 \%$ with concentrations of 50,000, 100,000 and 25,000 to 100,000 cells ml $^{-1}$ day $^{-1}$.

This study determined that in order to improve the mass culture of M. edulis, an initial stocking density of 10 larvae $\mathrm{ml}^{-1}$ and a daily food ration of 25,000 cells $\mathrm{ml}^{-1}$ of microalgae should be used for the larval stage. During the postlarval stage, the density that achieves an appropriate growth rate is 5 postlarvae $\mathrm{cm}^{-2}$ with an increasing food ration $\left(25,000\right.$ to 100,000 cells $\mathrm{ml}^{-1}$ day $\left.^{-1}\right)$ in a down-welling system. However for commercial purposes the settlement density should be close to 10 postlarvae $\mathrm{cm}^{-2}$.

Some challenges and unanswered questions are whether the parameters obtained for the larvae and postlarvae culture are static throughout the year and whether the technology developed is applicable to clam stocks from the southernmost latitudes. It is also necessary to couple the parameter estimations obtained with production costs and time of permanence in the hatchery and nursery to obtain of seeds for massive grow out.

\section{ACKNOWLedgments}

The authors wish to thank Humberto Monsalve and Rafael Sepúlveda, of Pesquera San José for providing facilities for the experiments and the technical team of the Hatchery for support and helpful comments; Lafayette Eaton for improving the manuscript. Finally we also thank FONDEF for their support to the development of the technology for culturing native species (Project D98I1081, AQ08I1027).

\section{LITERATURE CITED}

Abarca A, D Oliva, R Gutiérrez, Á Celis \& LR Duran. 2012. Growth of seeds of the taquilla clam Mulinia edulis (King $\&$ Broderip, 1832) in bottom cages: Acomparison of growth and survival in the subtidal and intertidal zone. Latin American Journal of Aquatic Research 40(3): 694-704.

Albentosa M, A Pérez-Camacho \& R Beiras. 1996. The effect of food concentration on the scope for growth and growth performance of Ruditapes decussatus (L) seed reared in an open-flow system. Aquaculture Nutrition 2: 213-220.

Beal BF \& MG Kraus. 2002. Interactive effects of initial size, stocking density, and type of predator deterrent netting on survival and growth of cultured juveniles of the soft-shell clam, Mya arenaria L., in eastern Maine. Aquaculture 208: 81-111.

Bustos E \& E Olavarria. 2000. Manual: El cultivo de la almeja (Venus antiqua), 19 pp. División de Acuicultura, Instituto de Fomento Pesquero, Talca.

Castagna M \& JN Kraeuter. 1981. Manual for growing the hard clam Mercenaria. Special Report in Applied Marine Science and Ocean Engineering 249: 1-110. Virginia Institute of marine Sciences, Gloucester Poin.

Coutteau P \& P Sorgeloos. 1992. The use of algal substitutes and the requirement for live algae and their replacement by artificial diets in the hatchery and nursery rearing of bivalve molluscs: an international survey. Journal of Shellfish Research 11: 467-476.

Doroudi M \& PC Southgate. 2000. The influence of algal ration and larval density on growth and survival of blacklip pearl oyster (Pinctada margaritifera L.) larvae. Aquaculture Research 31: 621-626.

Doroudi M, PC Southgate \& RJ Mayer. 1999. Growth and survival of blacklip pearl oyster larvae fed different densities of microalgae. Aquaculture International 7: 179-187.

Gallager S. 1988. Visual observation of particle manipulation during feeding in larvae of a bivalve mollusk. Bulletin of Marine Science 43: 344-365.

Gireesh R \& CP Gopinathan. 2008. Effects of microalgal diets on larval growth and survival of Paphia malabarica Chemnitz. Aquaculture Research 39: 552-556. 
Goldberg R. 1989. Biology and culture of the surf clam. In: Manzi JJ \& M Castagna (eds). Clam mariculture in North America. Developments in Aquaculture and Fisheries Science 19: 263-276. Elsevier, Amsterdam.

Hadley NH \& JJ Manzi. 1984. Growth of seed clams, Mercenaria mercenaria, at various densities in a commercial scale nursery system. Aquaculture 36: 369-378.

Helm MM \& N Bourne. 2004. Hatchery culture of bivalves. A practical manual. FAO Fisheries Technical Paper 471: 1-177.

Hurley D \& R Walker. 1996. The effect of larval stocking density on growth, survival, and development of laboratoryreared Spisula solidissima similis (Say, 1822). Journal of Shellfish Research 15: 715-718.

Hurley D, R Walker \& F O'Beirn. 1997. Growth and survival of Spisula solidissima similis larvae fed different rations of Tahitian Strain Isochrysis species. Journal of Shellfish Research 16: 151-157.

Jaramillo EH, H Contreras, O Garrido, C Gallardo, J NuìnPez \& G Jerez. 2008. Estudio de reproduccioìn y crecimiento del recurso Taquilla (Mulinia sp.) en la VIII y X Regioìn. Informe Final Proyecto FIP 2006- 51: 1-141. <http://www.fip.cl/FIP/Archivos/pdf/informes/ inffinal\%202006-51.pdf>

Jones GG, CL Sanford \& BL Jones. 1993. Manila clam: Hatchery and nursery methods, $50 \mathrm{pp}$. Innovative Aquaculture Products, Skerry Bay.

Liu B, B Dong, B Tang, T Zhang \& J Xiang.2006. Effect of stocking density on growth, settlement and survival of clam larvae, Meretrix meretrix. Aquaculture 258: 344-349.

Loosanoff VL \& HC Davis. 1963. Rearing of bivalve mollusks. Advances in Marine Biology 1: 1-136.

Manzi JJ \& M Castagna. 1989. Nursery culture of clams in North America. In: Manzi JJ \& M Castagna (eds). Clam mariculture in North America. Developments in Aquaculture and Fisheries Science 19: 127-148. Elsevier, Amsterdam.

Marshall R, S McKinley \& CM Pearce. 2010. Effects of nutrition on larval growth and survival in bivalves. Reviews in Aquaculture 2: 33-55.

O’Beirn FX, R Walker, D Hurley \& D Moroney. 1997. Culture of surfclams Spisula solidissima sp. in coastal Georgia: Nursery culture. Journal of Shellfish Research 16: 157-160.

Olavarría E, A Farías \& I Uriarte. 1996. Morfometría y tasa de crecimiento larvario y postlarvario de los bivalvos Venus antiqua (King \& Broderip, 1835) y Gari solida (Gray, 1828) cultivados en laboratorio. Revista de Biología Marina y Oceanografía 31: 107-116.
Oliva D, A Cifuentes, A Abarca, R Farlora, P Vera, LR Durán, J Urra, A Urra, D Brown, A Celis \& R Gutiérrez. 2005. Manual cultivo comercial de la almeja fina chilena, Mulinia edulis, 60 pp. Universidad de Valparaíso, Valparaíso.

Oliva D, A Abarca, R Gutierrez, A Célis, L Herrera \& V Pizarro. 2013. Effect of stocking density and diet on growth and survival of post-larvae of the taquilla clam Mulinia edulis cultivated in sand in a hatchery. Revista de Biología Marina y Oceanografía 48: 37-44.

Riisgard HU. 1988. Feeding rates in the hard clam (Mercenaria mercenaria) veliger larvae as a function of Isochrysis galbana algal concentration. Journal of Shellfish Research 7: 377-378.

Riisgard HU. 1991. Filtration rate and growth in the blue mussel, Mytilus edulis, Linnaeus, 1758: dependence on algal concentration. Journal of Shellfish Research 10: 29-35.

Royo A, M Quintero, M Hurtado-Burgos \& M HurtadoCanelo. 2002. Cultivo de almeja japonesa Ruditapes phiippinarum (Adams \& Reeve, 1850) a altas densidades de siembra y en zona intermareal. Boletín del Instituto Español de Oceanografía 18: 349-356.

Royo A, P Ruiz \& R Navajas. 2005. Preengorde intensivo de almeja japonesa Ruditapes phiippinarum (Adams \& Reeve, $1850)$ en sustrato, en la zona intermareal. Boletín del Instituto Español de Oceanografía 21: 447-454.

Sprung M. 1984. Physiological energetic of mussel larvae (Mytilus edulis). II. Food Uptake. Marine Ecology Progress Series 17: 295-305.

Sokal RR \& FJ Rohlf. 2012. Biometry: The principles and practice of statistics in biological research, 937 pp. Freeman and Company, New York.

Stotz W, M Valdebenito, M Romero, G Bernal, L Caillaux, J Aburto, H Contreras, D Lancellotti, N Urriola, P Guajardo, S Baro, G Aquea \& C Cerda. 2008. Estudio reproductivo del recurso almeja en la IV Regioìn. Informe Final Proyecto FIP 2006-46: 154. < http://www.fip.cl/FIP/ Archivos/pdf/informes/inffinal\%202006-46.pdf>

Vivanco G, D Oliva \& A Abarca. 2014. Efecto de dietas en base a microalgas tradicionales, nativas y dietas artificiales sobre el crecimiento y supervivencia en larvas velígeras de la almeja taquilla, Mulinia edulis. Revista de Biología Marina y Oceanografía 49: 339-349.

Yan X, G Zhang \& F Yang. 2006. Effects of diet, stoking density, and environmental factors on growth, survival, and metamorphosis of Manila clam Ruditapes philippinarum larvae. Aquaculture 253: 350-358. 